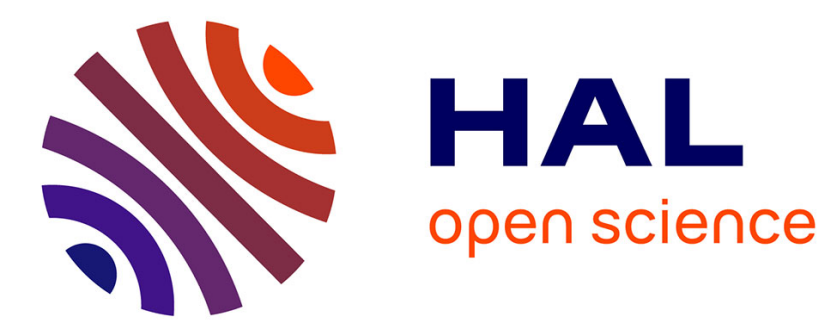

\title{
Impact of alternative jet fuels on aircraft-induced aerosols
}

Carolina Rojo, Xavier Vancassel, Philippe Mirabel, Jean-Luc Ponche, François

Garnier

\section{- To cite this version:}

Carolina Rojo, Xavier Vancassel, Philippe Mirabel, Jean-Luc Ponche, François Garnier. Impact of alternative jet fuels on aircraft-induced aerosols. Fuel, 2015, 144, pp.335-341. 10.1016/j.fuel.2014.12.021 . hal-01223234

\section{HAL Id: hal-01223234 \\ https://hal.science/hal-01223234}

Submitted on 18 Feb 2022

HAL is a multi-disciplinary open access archive for the deposit and dissemination of scientific research documents, whether they are published or not. The documents may come from teaching and research institutions in France or abroad, or from public or private research centers.
L'archive ouverte pluridisciplinaire HAL, est destinée au dépôt et à la diffusion de documents scientifiques de niveau recherche, publiés ou non, émanant des établissements d'enseignement et de recherche français ou étrangers, des laboratoires publics ou privés.

\section{(ㄷ)(1) $\$$}

Distributed under a Creative Commons Attribution - NonCommercial| 4.0 International 


\title{
Impact of alternative jet fuels on aircraft-induced aerosols
}

\author{
C. Rojo ${ }^{\text {a }}$, X. Vancassel ${ }^{\text {a }}$, P. Mirabel ${ }^{\text {b }}$, J.-L. Ponche ${ }^{\text {b }}$, F. Garnier ${ }^{\text {c,* }}$ \\ a Onera - The French Aerospace Lab, F-92322 Châtillon, France \\ ${ }^{\mathrm{b}}$ Institut de Chimie pour les Procédés, l'Énergie, l'Environnement et la Santé, UMR 7515, Université de Strasbourg, France \\ ' École de Technologie Supérieure (ÉTS), Montréal, QC H3C 1K3, Canada
}

\begin{abstract}
While using alternative aviation fuels represents a promising approach to reduce the industry's impact on climate change and local air quality, the influence of these new fuels on the chemical composition of exhaust plumes, and, in particular, on aviation-produced aerosols must be assessed. This paper studies the influence of using alternative jet fuels on induced particles, including contrails, in a near field of an aircraft.

A computational model with detailed microphysics taking into account the condensation of organic species, homogeneous freezing, and soot activation was used to study the effect of different fuels on the formation and evolution of particulate matter in the exhaust plume of an aircraft flying at cruise conditions.

Three different fuels were considered and compared: conventional kerosene (Jet A-1); a pure alternative fuel (with similar properties as Fischer-Tropsch (FT) or hydro-processed esters and fatty acids (HEFA) fuels); and a blend consisting of a 50/50 mixture of kerosene and the mentioned alternative fuel. Several conclusions can be drawn when using pure alternative and blended fuels instead of standard kerosene. The contribution of soluble organic matter in the composition of mixed aerosols increased on average by $29 \%$ with Jet A-1 to $45 \%$ with a blended fuel. The reduction in soot particles favors the homogeneous freezing pathway and the ice crystals formed were larger and evidenced lower number densities. The background particles can no longer be neglected, since they can account for more than $50 \%$ of the particles after $5 \mathrm{~s}$ behind the nozzle exit. All these changes are expected to alter the optical properties of contrails.
\end{abstract}

\section{Introduction}

Aviation has a direct impact on climate, on atmospheric composition at flight altitudes, and on local air quality in the vicinity of airports, since it releases gases such as carbon dioxide, nitrogen and sulfur oxides, as well as particulate matter (soot).

These emissions are also responsible for new particle formation in the plume, including aerosols and contrails. Of particular interest are the climatic effects of these particles, since aerosols are

\footnotetext{
* Corresponding author. Tel.: +1 5143968425.

E-mail address: Francois.Garnier@etsmtl.ca (F. Garnier).
}

known to have a potential impact on climate, either by direct or indirect radiative forcing. Through direct radiative forcing, they affect the scattering of solar radiation and the absorption/emission of terrestrial radiation. Through indirect forcing, they interact with clouds, leading to changes in cloud reflectivity and lifetime. Persistent contrails can spread out and become high-altitude cirrus clouds. They cool the climate by reflecting incoming sun radiation back into space, but they also trap infrared radiation emitted by the earth surface, leading to a warming effect. All these climatic effects are strongly correlated to particle properties (number density, size distribution, and composition), which, in turn, depend on the type of fuel burned. 
Aviation is a fast growing sector of the economy and, as air traffic keeps increasing, these environmental issues become more important. Scientists are working on various options for mitigating aviation's future impact on the atmosphere [1].

A viable choice for reducing this impact may be using alternative fuels. In addition to benefiting the environment, this would also be a step toward achieving energy independence from petrol-based fuels. Indeed, as the price of a barrel of oil rises, other energy sources are explored and favored [2].

Therefore, this research aimed at studying the influence of using alternative jet fuels on induced particles in an aircraft plume with a detailed microphysical model. Three different jet fuels were tested, including regular kerosene (Jet A1), an alternative fuel (with similar properties as Fischer-Tropsch (FT) or hydro-processed esters and fatty acids (HEFA) jet fuel), and a blend consisting of a 50/50 mixture of kerosene and alternative fuel.

\section{Alternative fuels}

Various types of alternative fuels have been tested in commercial aviation. These fuels must meet several criteria that concern diverse areas [3], such infrastructure compatibility, the similarity of the fuel's properties, and the environmental and financial cost of its development. The alternative fuels likely to be used in the near future are the "drop-in" fuels, that is, fuels that can be used with current infrastructure and engines [4], and that can also be blended with standard aviation fuel (Jet A1) without altering the fuel's properties. This type of fuel can be considered as a potential replacement for conventional kerosene. Alternative fuels should have characteristics similar to standard fuels for safety reasons. For instance, their properties have to be constant within the large temperature and pressure variations commonly encountered during flight (from $-60{ }^{\circ} \mathrm{C}$ at $150 \mathrm{hPa}$ to up to $50^{\circ} \mathrm{C}$ at ground levels).

Another major concern, which has to be taken into account when developing an alternative fuel, is efficient land use so as to avoid competition with food production or water resources. Additionally, these new fuels should emit lower life-cycle greenhouse gases to be beneficial for the environment [3]. To this end, several processing pathways are currently being investigated such as fuels with Fischer-Tropsch (FT) synthesis or hydro-processed esters and fatty acids (HEFA, formerly known as HRJ). FT fuels can be produced from various sources such as coal ( $\mathrm{CtL}$ ), gas (GtL), biomass (BtL), and mixed coal and biomass (CBtL). BtL fuels, however, are more beneficial for the environment, since they induce a reduction of carbon-dioxide emissions across their life cycles. HEFA jet fuels can be produced from animal fat or biomass (e.g., waste cooking oil). Since 2011, many airline companies have integrated these new sustainable fuels in their flights after certification. The fuels are generally blends of $20 \%$ to up to $50 \%$ of FT or HEFA fuels [5]. A recent European directive (2009/2/EC) promotes the use of biofuels in the transportation sector to reach a goal of $10 \%$ of alternative fuels used by 2020 [6].

The introduction of new fuels in aviation is likely to modify the chemical composition of turbine-engine exhaust and therefore affect the evolution of aircraft-produced aerosols. In turn, these changes in aerosol composition and surface properties will impact particle growth and contrail formation. Therefore, the influence of these new jet fuels on the entailed emissions in the near field of an aircraft must be assessed.

Comprehensive studies have been conducted on aerosol formation in aircraft plumes for typical kerosene [7-11] but the few studies available for alternative fuels mostly concern emission characterization [12-14]. Typically, synthetic fuels have lower sulfur and aromatic contents than kerosene. For example, Timko et al. [12] showed that the aromatic content of the JP-8 fuel was

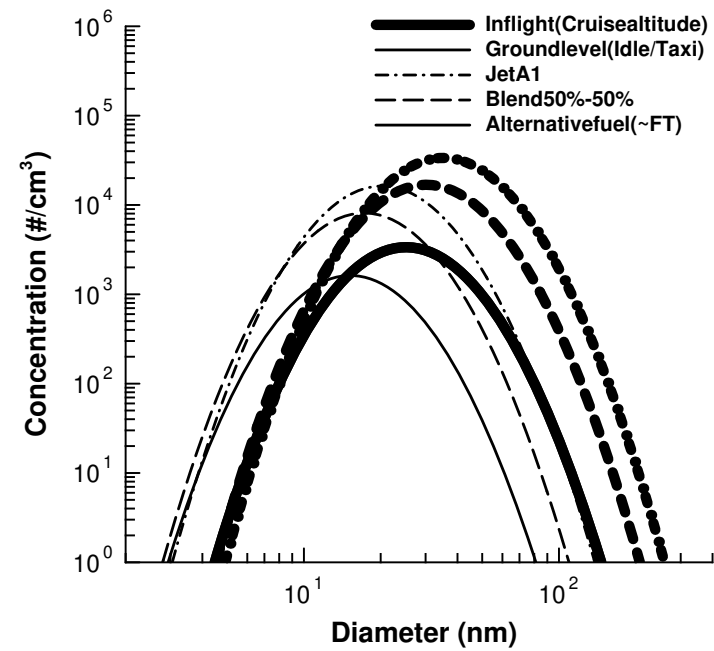

Fig. 1. Initial emitted soot number densities and diameters for kerosene, pure alternative fuel, and a 50/50 mixture of kerosene and alternative fuel, from Table 1.

19 vol\%, whereas the fuel aromatic content of the synthetic fuel (Fischer-Tropsch fuel) was below the method's detection limits. As a consequence, reducing the aromatic content will decrease the production of soot particles. Their diameters vary from $35 \mathrm{~nm}$ for Jet A-1 to $25 \mathrm{~nm}$ for $100 \%$ alternative fuel at cruise conditions, and from 20 to $14 \mathrm{~nm}$ at idle $[12,15,16]$. Based on these data, Fig. 1 summarizes the variation of the soot number densities and sizes associated with the different fuels used in this study. Finally, the fuel sulfur content (FSC) generally ranges from 300 and $800 \mathrm{ppm}$ (with a maximum allowed of $3000 \mathrm{ppm}$ ) for standard jet fuel. As alternative fuels are extra low sulfured, the FSC of a blend, depending on the percentage of alternative fuel incorporated, will reduce the formation of ultrafine acidic aerosols. Throughout the rest of this study, the pure alternative fuel referred to is therefore characterized by an extra low sulfur content and a very low aromatic content as are both FT and HEFA fuels, the main alternative fuels tested and certified for aviation $[13,16]$.

Herein, the influence of using alternative jet fuels on induced particles in an aircraft plume was modeled, using detailed microphysics and simple dilution models. Three different jet fuels were tested: regular kerosene (Jet A1), a pure alternative fuel, and a blend consisting of a 50/50 mixture of kerosene and alternative fuel.

\section{Aircraft-plume microphysical model}

During flight, ambient air is sucked up by the jet engine and at the engine nozzle exit, where the temperature is around 580-600 K. The jet rapidly mixes with ambient air and the plume undergoes very fast cooling and dilution. During the early stage of the cooling, some of the gases released in the engine jet undergo phase transitions leading to aerosol formation. In particular, sulfur contained in the fuel leads to the formation of sulfur oxides in the plume, which are partly converted into sulfuric acid [17], which is known to promote aerosol formation through heteromolecular nucleation with water vapor.

Note that, during the mixing with ambient air, background aerosols are entrained and can provide additional condensation nuclei. They were introduced into the calculation and their relative importance is supposed to increase when burning alternative fuels.

The process of aerosol formation was simulated using a trajectory box model (e.g., $[9,18])$, characterizing aerosol microphysical properties in a parameterized jet plume, diluted isobarically and 
homogeneously in the atmosphere. Herein, the plume mixing was treated with a parameterized overall dilution ratio as expressed by a formula based on aircraft plume measurements [19]:

$D(t)=\frac{\text { AFR }}{7000\left(t / t_{0}\right)^{0.8}}$

with $t_{0}=1 \mathrm{~s}$ as arbitrary reference scale and AFR for air-fuel ratio (AFR $=60$ ).

This simplified model is convenient to take into account all the main processes of transformation of gaseous and particulate combustion products in a comprehensive manner.

The microphysical model we used was first developed by Sorokin et al. [9]; Vancassel et al. [20]. It was adapted, however, to simulate the combustion of alternative fuels and numerous parameters were revised. It provides 11 types of aggregates (Neutral and Negative Sulfate Clusters) and particles (Dry Soot, Activated Soot, Neutral and Positive Organic Clusters, Neutral Positive and Negative Mixed Aerosol, Ice Particles homogeneously and heterogeneously formed).

The model considers an initial mixture of water vapor, sulfuric acid, organics, soot particles and chemi-ions. Chemi-ions are typically positive organic clusters and negative sulfate [21].

Apart from water, other condensable species participate in aerosol growth. That is the case of the organic species. Particular attention was given to their presence, since they tend to modify water uptake by changing the particle composition and therefore the respective components' mole fractions and activities. The question of the hygroscopic behavior of organics is difficult to address and, in an initial attempt, we used the assumption that the organic hygroscopicity was lower than that of sulfuric acid as suggested by Kärcher and Koop [22].

In addition, we distinguished two types of organic species: organic compounds that are soluble in water and the organic compounds considered insoluble in water [23]. The former are considered to form organic hydrated clusters in a way similar to sulfuric acid and water [24]. The initial distribution of organic hydrated clusters obtained, concerning the first type of organic species, consequently interact with the other aerosols in the aircraft plume mainly by collision. The latter are considered to be adsorbed onto the soot surface, which is not already covered by an aqueous solution of sulfuric acid and soluble organic compounds [25,26]. The adsorption of insoluble organic compounds on soot entails the formation of two distinct non-miscible phases [27]. Therefore, during the condensation of volatile particles on soot, a competition between soluble and insoluble species takes place.

The main difficulty was selecting an organic surrogate for each of the two groups, whose properties would characterize all of the compounds present in the group. Indeed, very many different organic species have been measured at the nozzle exit during NASA, FAA and EEA campaigns [28-33].

Based on their thermodynamic properties-such as boiling point and vapor pressure-we considered acetaldehyde $\left(\mathrm{C}_{2} \mathrm{H}_{4} \mathrm{O}\right)$ to represent the bulk of soluble organic compounds and pyrene $\left(\mathrm{C}_{16} \mathrm{H}_{10}\right)$ to characterize the whole of the insoluble organic compounds.

The amounts of organic compounds in each of the two groups were determined based on the measurements carried out by Spicer et al. [28]; Knighton et al. [34], which indicate larger quantities of soluble than insoluble organic matter (OM).

Selecting these specific organic compounds influences the aerosol's properties, more precisely, their density, surface tension, and activity in the solution, since all of these parameters impact their rate of growth.

The density and surface tension of a liquid mixture of sulfuric acid, water acetaldehyde, and pyrene are not known. Therefore, they were estimated based on Brock and Bird [35]; Sastri and Rao [36]; Poling et al. [37]. Similarly, the activity coefficients of aerosols, which are important parameters influencing water uptake, hence affecting particle growth, were estimated with the method described by Jun [26]. This method takes into account the specific affinity between water and sulfuric acid, as well as the affinity between water and soluble organic compounds. It also assumed that interactions between sulfuric acid and organic compounds in aqueous solutions are negligible [38]. Insoluble organic compounds do not affect the activity coefficients in the solution, since they are considered to form a distinct phase [27]. Based on these assumptions, the water activity $a_{w}$ in the mixture is expressed as:

$a_{w}=a_{w, \mathrm{H}_{2} \mathrm{SO}_{4}} \times a_{w, \mathrm{SOM}}$

where $a_{w, \mathrm{H}_{2} \mathrm{SO}_{4}}$ is the water activity in an aqueous solution of sulfuric acid and $a_{w, \text { Som }}$ the water activity in the aqueous organic solution.

Finally, ice formation through freezing mechanisms has been considered either heterogeneously (when a soot core is included) or homogeneously (from a liquid droplet). Generally, the latter is neglected in relation to the former, notably when conventional kerosene is used, due to the large amounts of condensation nuclei and due to the acidity of the aqueous mixture. Since the combustion of alternative fuels, however, emits a significantly reduced number of soot particles, these two freezing pathways are expected to compete $[39,40]$.

\section{Results and discussion}

We simulated the evolution of aerosols generated during the combustion of alternative jet fuels in the near field of an aircraft using the adapted microphysical model. We focused on cruise altitudes at which aircraft emissions may have a major influence on radiative forcing and, consequently, on climate. Typical atmospheric conditions encountered at a pressure level of $225 \mathrm{hPa}$ corresponding to a cruise altitude of $\sim 34,000$ feet were used for our simulations. The ambient relative humidity and temperature were $46 \%$ and $218.8 \mathrm{~K}$, respectively. Under these conditions, contrails may form.

As already described, three types of fuels were used: conventional kerosene (Jet A-1); a pure alternative fuel; a blend consisting of a 50/50 mixture of kerosene and alternative fuel. The engine setting was $\sim 60 \%$ of full power; Table 1 summarizes the typical averaged emissions from their combustion. Recent literature values for the sulfur conversion rate range from $1 \%$ to $5 \%[10,41,42]$. In our simulations, a value of $3 \%$ was used as suggested by Schumann et al. [43]. Finally, the amount of chemi-ions considered at the nozzle exit equals $2 \times 10^{17} \mathrm{~cm}^{-3}[21,44,45]$.

\subsection{Results without accounting for ambient particles}

Fig. 2 illustrates the size distributions of particulate matter in the aircraft plume $0.5 \mathrm{~s}$ behind the nozzles (equivalent to $\sim 125 \mathrm{~m}$ ) for these three fuels. Four different modes are distinguished: the first mode, centered at about $1 \mathrm{~nm}$, represents mainly hydrated clusters of sulfuric acid and organic compounds. These are still considered belonging to the gas phase. The second mode is formed by volatile particles, whose size ranges from several $\mathrm{nm}$ to several hundred $\mathrm{nm}$. The third mode represents soot particles, with diameters around $30 \mathrm{~nm}$ at the nozzle exit. This size can increase, due to water vapor condensation, to up to almost $1 \mu \mathrm{m}$ just before freezing. Lastly, the fourth mode consists of ice crystals and is centered at a few microns.

The combustion of pure kerosene formed a rather large amount of sulfuric acid and an important number of soot particles were 
Table 1

Reference fuel and emission data used herein.

\begin{tabular}{|c|c|c|c|c|}
\hline Fuel & Jet A1 or JP8 & $50 \%$ Blend & Alternative fuel & References \\
\hline Soot $\left(\# / \mathrm{m}^{3}\right)$ & $8.10^{11}$ & $4.10^{11}$ & $8.10^{10}$ & Schumann et al. [43]; Corporan et al. [57]; Ziemba et al. [15] \\
\hline $\mathrm{FSC}^{\mathrm{a}}(\mathrm{ppm})$ & 600 & 300 & Traces $(\sim 2)$ & Hileman et al. [58] \\
\hline $\mathrm{EI}_{\mathrm{OM} 1}^{\mathrm{b}}\left(\mathrm{mg} \mathrm{kg}^{-1}\right.$ fuel $)$ & 35 & 40 & 45 & Spicer et al. [59]; Slemr et al. [29]; Knighton et al. [34]; Timko et al. [12] \\
\hline $\mathrm{EI}_{\mathrm{OM} 2}{ }^{\mathrm{c}}$ (mg kg ${ }^{-1}$ fuel $)$ & 15 & 10 & 5 & \\
\hline
\end{tabular}

a Fuel sulfur content in ppm by mass.

b Emission index of type 1 soluble organic compounds, expressed in mg per kg-1 fuel.

c Emission index of type 2 insoluble organic compounds, expressed in mg per $\mathrm{kg}^{-1}$ fuel.

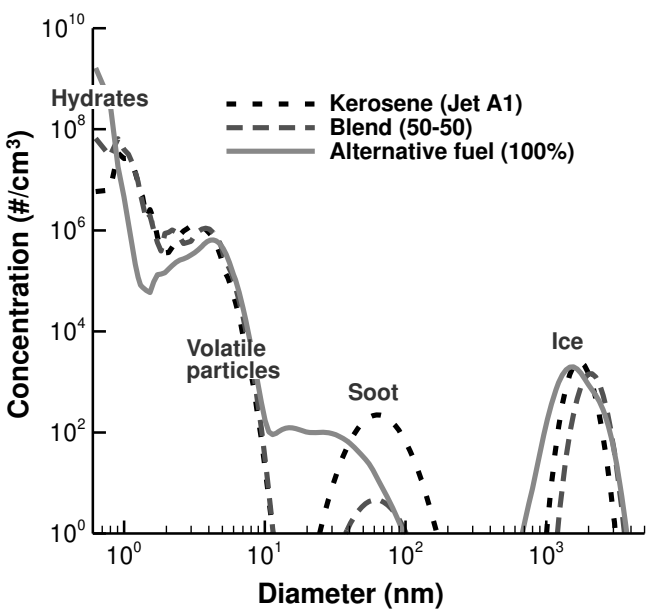

Fig. 2. Size distributions of aerosols emitted and formed in aircraft plumes at $125 \mathrm{~m}$ behind the engine nozzle, using various fuels. Black dots for a standard kerosene; red dashes for a $50 / 50$ blended fuel (alternative/Jet A-1); and green solid for a $100 \%$ alternative fuel. (For interpretation of the references to color in this figure legend, the reader is referred to the web version of this article.)

released. A major fraction of these soot particles was quickly activated by adsorption of the acid; subsequent condensation of volatile species-mainly water-may occur. In this case, ice crystals are formed from these mixed soot particles covered with water, sulfuric acid, and organic compounds. Not all activated soot particles froze, as can be observed by the presence of the large third mode centered at $\sim 70 \mathrm{~nm}$. The curve for the blend shows a similar behavior, except for the large reduction of activated soot concentration (diameters around $70-80 \mathrm{~nm}$ ). Half a second behind the aircraft, this concentration decreased from $\sim 200 \mathrm{soot} / \mathrm{cm}^{3}$ for kerosene to $\sim 10 \operatorname{soot} / \mathrm{cm}^{3}$ (factor of 20), while the emitted soot was only reduced by a factor of 2 . This large reduction can be explained by a larger fraction of activated soot that froze, leading to ice particles. Indeed, the same amount of water vapor is available to condense on fewer soot particles, which contributes to their enhanced growth and freezing.

The shape of the curve corresponding to $100 \%$ alternative fuel is quite different, especially for sizes below $100 \mathrm{~nm}$. For example, there is a slight reduction of small volatile particles due to the quasi-absence of sulfuric acid in the plume. In addition, the lack of sulfuric acid does not allow the activation of soot particles. Indeed, as previously shown, a minimum amount of sulfuric acid is necessary to form a coating that triggers the condensation and growth of soot particles [46-51]. Therefore, when $100 \%$ alternative fuel is combusted, the soot distribution remains barely coated at smaller diameters, corresponding roughly to its size when emitted.

Different consequences on ice formation were observed. Firstly, in both the kerosene and blend cases, heterogeneous freezing was the dominant mechanism. Therefore, a reduction in the concentration of mixed soot, as in the case of the blend, entailed a slight reduction in the number of crystals (about $50 \%$ ), accompanied by a slight increase in crystal size (from $1.5 \mu \mathrm{m}$ with kerosene to $2 \mu \mathrm{m}$ with the blend). Secondly, when the alternative fuel was used, the lack of activated soot in the plume promoted the homogeneous ice-forming pathway. The ice crystals observed in Fig. 2 were consequently formed without a soot core. The size distribution obtained for the ice particles is roughly the same as that for the ice formed when kerosene was used, but the distribution was slightly wider. These variations in crystal properties may influence the optical depth of the formed condensation trail and, hence, impact the radiative budget.

Modifying the fuel used in aviation may also have an impact on the water and ice saturation ratios in the plume, as illustrated in Fig. 3a. Independently of the fuel used, aircraft plumes become supersaturated at around $0.1 \mathrm{~s}$. When burning an alternative fuel, however, supersaturated conditions last longer. This phenomenon can be explained by the fact that fewer activated soot particles are present in the plume, therefore less water condenses onto their surfaces and a larger amount of water remains in the gas phase.

Fig. $3 \mathrm{~b}$ shows the mean sizes of the different types of particulates during plume dilution for the three cases studied. As the water saturation ratio exceeded 1 , the volatile particles grew significantly for the three fuels modeled, particularly pure alternative fuel, for which they were as much as $10^{-7} \mathrm{~m}$. This later case can be explained by the longer supersaturation conditions and larger availability of water vapor due to the lack of mixed soot particles.

The mixed soot particles grew to large sizes $\left(10^{-6} \mathrm{~m}\right)$ for the kerosene and the blend cases (black), contrarily to those formed from pure alternative fuels, which were not activated as explained above. In the first two cases, ice crystals formed heterogeneously rapidly after supersaturation at $\sim 0.2 \mathrm{~s}$, which is in agreement with past studies [8]. When alternative fuel was combusted; the homogeneous ice, however, was formed slightly later, since volatile particles need to grow larger for its formation. As the plume returned to undersaturated conditions with respect to water, the mixed soot and volatile particles decreased in size (Fig. 3b), while ice size remained stable, since the plume was still supersaturated with respect to ice.

As illustrated in Fig. 4, the type of jet fuel affected the mixed soot-particle composition, since, as already noted, soot act as condensation nuclei, uptaking condensable gaseous species such as water, sulfuric acid, and organic matter. The mean composition of these mixed soot particles at $1 \mathrm{~s}$ after emission is shown only for kerosene and blended fuels, since the few soot particles with $100 \%$ alternative fuel were not activated and therefore did not act noticeably as condensation nuclei. With the standard kerosene, sulfuric acid accounted for $11 \%$ of the particle volume, organic matter for $29 \%$, and water for $53 \%$, whereas the soot core represented only $7 \%$ of the volume.

On the one hand, when the blended jet fuel was combusted, the reduced production of sulfuric acid in the aircraft plumes decreased the volume fraction of sulfuric acid coating the soot (7\%). Therefore, the amount of water balancing the uptake of $\mathrm{H}_{2} \mathrm{SO}_{4}$ was also reduced. On the other hand, however, the increased emission of soluble organic compounds accounts for their larger 

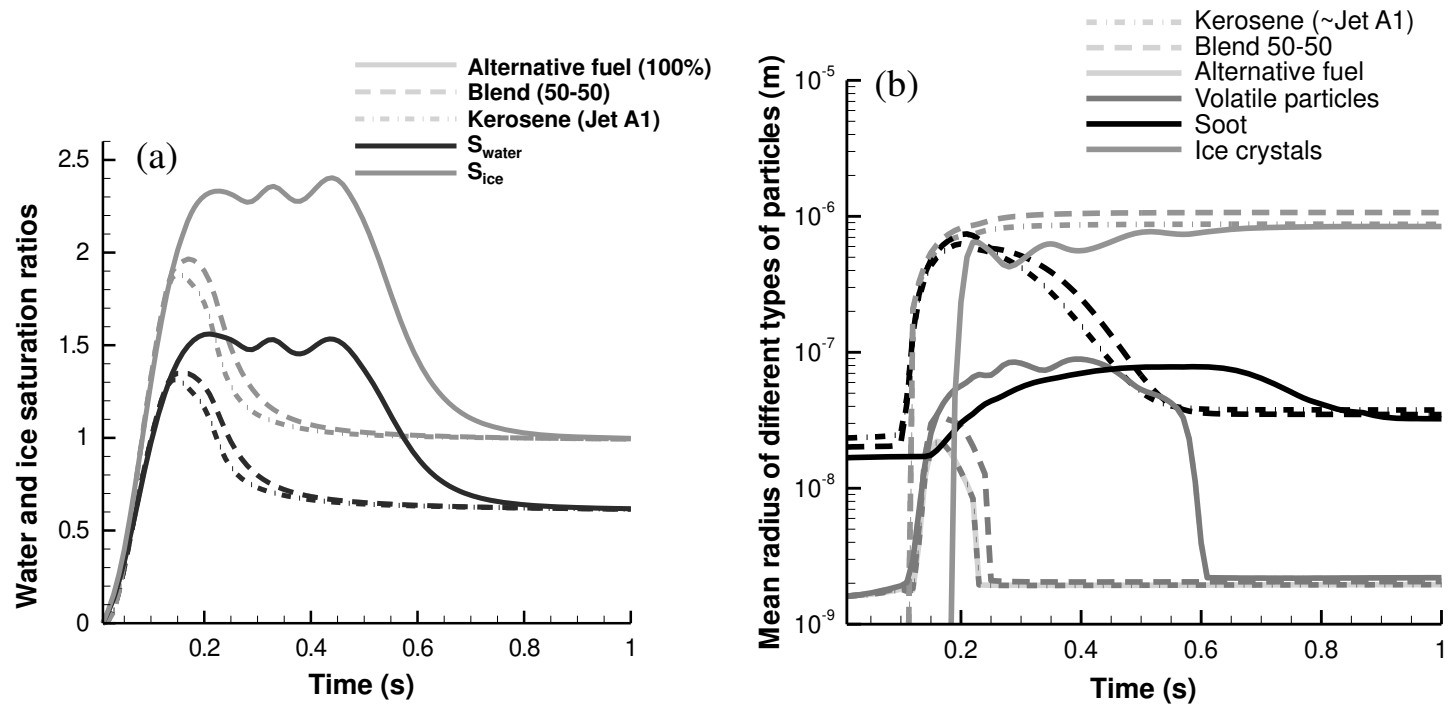

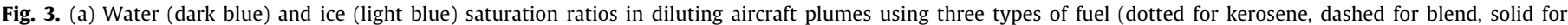

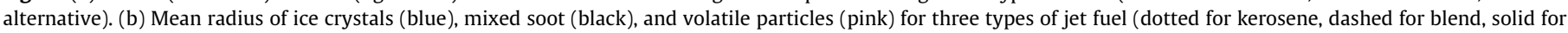
alternative). (For interpretation of the references to color in this figure legend, the reader is referred to the web version of this article.)

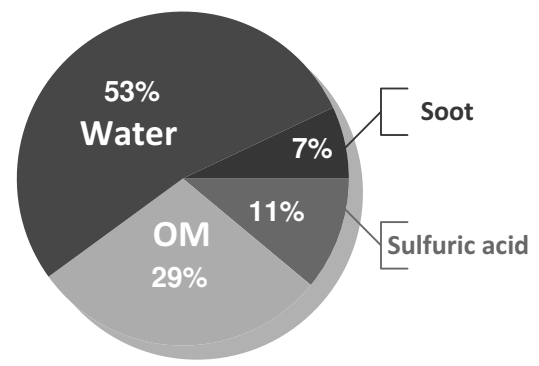

(a) With kerosene

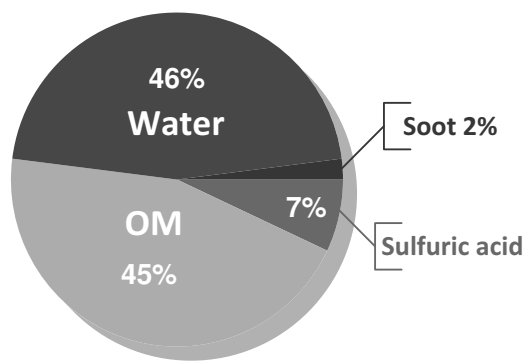

(b) With a 50/50 blend

Fig. 4. Mean volume composition of mixed soot in plumes $250 \mathrm{~m}(1 \mathrm{~s})$ behind the aircraft.

uptake by soot and was accompanied by additional water hydrating the particle. Overall the decreased amount of water due to the reduced $\mathrm{H}_{2} \mathrm{SO}_{4}$ uptake was nearly compensated for by the amount hydrating the increased OM coating. Furthermore, the reduction of emitted soot led to a larger availability of condensable species per soot particle, explaining the decreased fraction of soot core for the blended fuel (2\%).

These results may be useful in determining the impact of aircraft plumes on climate, since the composition of soot particles is known to alter plume optical properties and therefore plume radiative forcing on the atmosphere [51-53]. Indeed, the soot particles were involved in the freezing processes and might also alter the contrail's optical properties. The changes in radiative forcing induced by the introduction of alternative fuels in aeronautics still need to be assessed.

\subsection{Effect of ambient particles}

The ambient particles were taken into account while modeling the three types of fuels. The drastic reduction of soot emissions when burning alternative fuels leads to the consideration of the often-neglected effects of the entrainment of ambient particles. Their contribution in the plume is expected to increase when burning alternative fuels, especially when flying in aircraft corridors.

Their presence was introduced into the model and their properties (size, composition, and number density) were considered based on the work of Schröder et al. [54], Deshler et al. [55], and
Kärcher et al. [56]. The latter suggested an ambient soot-particle concentration of $500 / \mathrm{cm}^{3}$. Fig. 5 depicts the influence of fuel type on the relative importance of the emitted soot and the entrained ambient particles as a function of time in the plume.

When standard kerosene is combusted, the contribution of emitted soot predominates, whereas the fraction of entrained soot can be neglected (dashed). Indeed, as far as $2.5 \mathrm{~km}(10 \mathrm{~s})$ behind the aircraft, the proportion of entrained soot in the plume accounts for less than $20 \%$ of total soot particles, justifying the fact that ambient particles are generally neglected when studying particle evolution in the near field of an aircraft.

When using alternative fuels, however, the soot emissions diminish significantly, which induces a larger contribution of ambient soot. For example, burning the blended fuel increased the contribution of entrained soot from $5 \%$ to $15 \%$ at $4 \mathrm{~s}$ behind the nozzles, whereas it increased up to $50 \%$ with pure alternative fuel. After $4 \mathrm{~s}$, the entrained particulates predominated in the latter case. The supply of additional ambient particles is therefore not negligible and can alter the evolution of the particulate matter and its properties, such as mean composition, in the aircraft plume.

Fig. 6 illustrates the size distribution of particles in an aircraft plume $1 \mathrm{~s}$ after exiting the engine using pure alternative fuel. In this case, as already indicated, the ambient particles can have a very significant influence on the final size distribution. In their presence, volatile particles cannot grow to larger sizes, since many of them have been collected by ambient mixed soot, limiting their growth by coagulation. The soot and mixed soot modes are now 


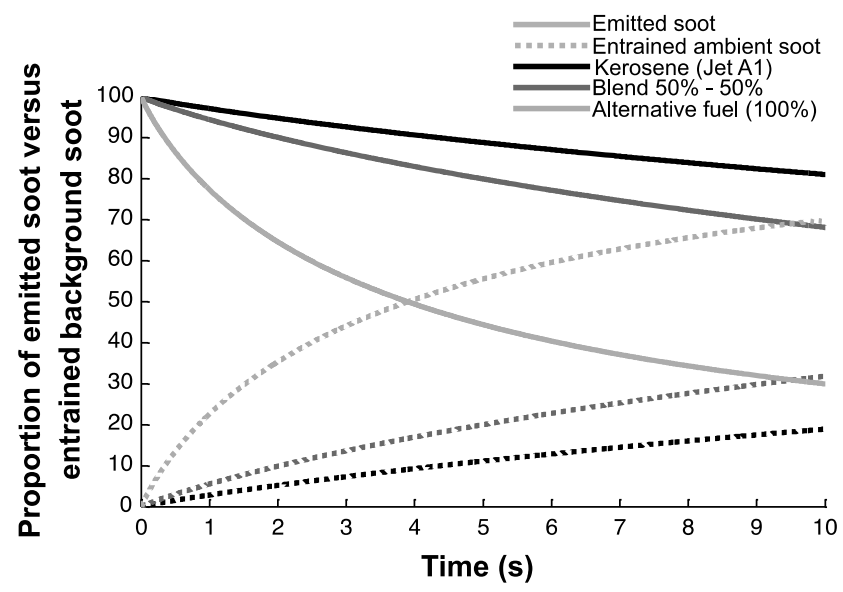

Fig. 5. Contributions of ambient particles vs. emitted soot during the dilution of three aircraft plumes using various fuels. Black for standard kerosene; red for 50/50 blended fuel (alternative/Jet A-1); green for $100 \%$ alternative fuel; solid for soot emissions; and dashed for entrained ambient particles. (For interpretation of the references to color in this figure legend, the reader is referred to the web version of this article.)

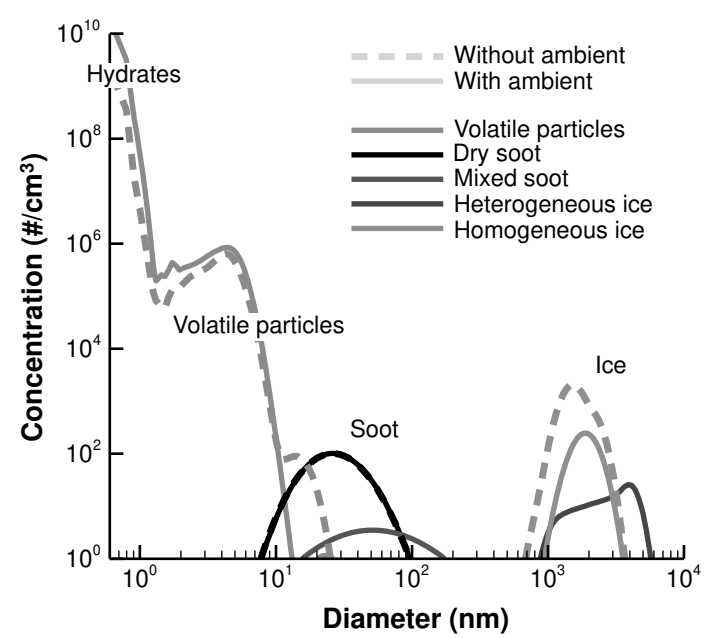

Fig. 6. Size distribution of aerosols in an aircraft plume using alternative fuel, with (solid line) and without (dashed line) taking into account the background aerosols at $1 \mathrm{~s}$ behind the nozzles (orange for volatile particles, black for dry soot, gray for mixed soot, light blue for homogeneous crystals, and dark blue for heterogeneous crystals). (For interpretation of the references to color in this figure legend, the reader is referred to the web version of this article.)

visible and these modes resulted solely from the presence of ambient particles, since FT or HEFA combustion dramatically reduces soot-particle production.

Finally, a competition concerning the freezing paths is also evident. Indeed, when the ambient aerosol is neglected, the predominant pathway of ice formation is homogeneous. The supply of condensation nuclei coming from the ambient particles, however, enhances heterogeneous freezing. In this case, the importance of the homogeneous pathway decreased compared to the former, and both ice modes were now observed.

\section{Conclusion}

Three different fuels were compared: conventional kerosene (Jet A1), an alternative fuel (with similar properties as FT or HEFA jet fuels), and a blend consisting of a 50/50 mixture of kerosene and the mentioned alternative fuel. The major differences between standard aviation fuel (Jet A-1) and the alternative fuel considered are sulfur content (typically $600 \mathrm{ppm}$ for kerosene and $\sim 0 \mathrm{ppm}$ for alternative fuel) and aromatic content, (negligible for alternative fuel and about $19 \mathrm{vol} \%$ for kerosene). The $50 / 50$ blend was assumed to have intermediate properties. Consequently, pure alternative fuel will produce fewer soot particles (ten times less in our simulations) and will only produce traces of sulfuric acid, which is known to be the origin of submicronic acidic aerosols.

Several conclusions can be drawn when using alternative fuel instead of regular kerosene, and these conclusions can be slightly different if ambient particles are ignored, as it is usually the case, or introduced in the model.

In addition, the mixed-soot particles mean composition could be significantly modified as the volume of organic matter increased from $29 \%$ to $45 \%$ when kerosene and the blended fuel were burned, respectively. However, when pure alternative fuel was combusted the soot particles were barely coated and their distribution remains at smaller diameters, corresponding roughly to the size when emitted.

When using kerosene and the 50/50 blend, the ice crystals formed primarily through heterogeneous freezing, but when pure alternative fuel was burned, the emitted soot particles are not activated and ice crystals were formed via homogeneous freezing instead. However, the final size distribution of ice particles remained approximately the same.

As the combustion of alternative fuels leads to a large reduction in volatile particle formation and in soot emissions, the background particles must be taken into account. They can indeed represent more than $50 \%$ of the particles, after $5 \mathrm{~s}$ behind the aircraft nozzles. Their introduction in the model led to a modification of the size distribution of the volatile particles distribution, since they can be now uptaken by the ambient particles, the soot and mixed soot modes were re-introduced, resulting solely from the presence of ambient particles. Finally, a competition between homogeneous and heterogeneous freezing paths was noticed, modifying the final distribution of ice particles.

\section{References}

[1] Lee DS, Fahey DW, Forster PM, Newton PJ, Wit RCN, Lim LL, et al. Aviation and global climate change in the 21st century. Atmos Environ 2009:43:3520-37.

[2] Blakey S, Rye L, Wilson CW. Aviation gas turbine alternative fuels: a review. Proc Combust Inst 2011;33:2863-85.

[3] Stratton RW, Wong HM, Hileman JI. Life cycle greenhouse gas emissions from alternative jet fuels. Partnersh AiR Transp Noise Emiss Reduct Mass Inst Technol Camb MA 2010.

[4] DeWitt MJ, Corporan E, Graham J, Minus D. Effects of aromatic type and concentration in Fischer-Tropsch fuel on emissions production and material compatibility. Energy Fuels 2008;22:2411-8.

[5] ATAG. ATAG: Air Transp Action Group n.d.

[6] IFP. IFP Energies nouvelles n.d.

[7] Kärcher B. Physicochemistry of aircraft-generated liquid aerosols, soot, and ice particles 1. Model description. J Geophys Res 1998;103(17):111-7128.

[8] Yu F, Turco RP. The formation and evolution of aerosols in stratospheric aircraft plumes: numerical simulations and comparisons with observations. J Geophys Res 1998;103:25915-34.

[9] Sorokin A, Vancassel X, Mirabel P. On volatile particle formation in aircraft exhaust plumes. Phys Chem Earth Part C Sol Terr Planet Sci 2001;26:557-61.

[10] Vancassel X, Sorokin A, Mirabel P, Petzold A, Wilson C. Volatile particles formation during PartEmis: a modelling study. Atmos Chem Phys 2004;4:439-47.

[11] Paoli R, Vancassel X, Garnier F, Mirabel P. Large-eddy simulation of a turbulent jet and a vortex sheet interaction: particle formation and evolution in the near field of an aircraft wake. Meteorol Z 2008;17:131-44.

[12] Timko MT, Yu Z, Onasch TB, Wong H-W, Miake-Lye RC, Beyersdorf AJ, et al. Particulate emissions of gas turbine engine combustion of a Fischer-Tropsch synthetic fuel. Energy Fuels 2010;24:5883-96.

[13] Anderson BE, Beyersdorf AJ, Hudgins CH, Plant JV, Thornhill KL, Winstead EL et al. Alternative aviation fuel experiment (AAFEX); 2011.

[14] Beyersdorf AJ, Timko MT, Ziemba LD, Bulzan D, Corporan E, Herndon SC, et al Reductions in aircraft particulate emissions due to the use of Fischer-Tropsch fuels. Atmos Chem Phys 2014;14:11-23.

[15] Ziemba LD, Beyersdorf AJ, Hudgins CH, Liscinsky DS, Thornhill KL, Winstead EL et al. Concentrations and physical properties of exhaust particles from aircraft engines burning standard and synthetic fuels: AAFEX results; 2011. 
[16] Anderson B. NASA alternative aviation fuel research: AAFEX-II overview and results; 2012.

[17] Reiner T, Arnold F. Laboratory investigations of gaseous sulfuric acid formation via $\mathrm{SO}_{3}+\mathrm{H}_{2} \mathrm{O}+\mathrm{M} \rightarrow \mathrm{H}_{2} \mathrm{SO}_{4}+\mathrm{M}$ : measurement of the rate constant and product identification. J Chem Phys 1994;101:7399-407.

[18] Kärcher B. A trajectory box model for aircraft exhaust plumes. J Geophys Res 1995;100:18835-44.

[19] Schumann U, Schlager H, Arnold F, Baumann R, Haschberger P, Klemm O. Dilution of aircraft exhaust plumes at cruise altitudes - in situ measurements and predictions. Atmos Environ 1998;32:3097-103.

[20] Vancassel XP, Garnier FA, Mirabel PJ. In plume physics and chemistry. Encycl Aerosp Eng 2010.

[21] Arnold F, Kiendler A, Wiedemer V, Aberle S, Stilp T, Busen R. Chemiion concentration measurements in jet engine exhaust at the ground: implications for ion chemistry and aerosol formation in the wake of a jet aircraft. Geophys Res Lett 2000;27:1723-6.

[22] Kärcher B, Koop T. The role of organic aerosols in homogeneous ice formation. Atmos Chem Phys 2005;5:703-14.

[23] Turpin BJ, Saxena P, Andrews E. Measuring and simulating particulate organics in the atmosphere: problems and prospects. Atmos Environ 2000;34:2983-3013.

[24] Yu F, Turco RP, Kärcher B. The possible role of organics in the formation and evolution of ultrafine aircraft particles. J Geophys Res 1999;104:4079-87.

[25] Wang L, Khalizov AF, Zheng J, Xu W, Ma Y, Lal V, et al. Atmospheric nanoparticles formed from heterogeneous reactions of organics. Nat Geosci 2010;3:238-42.

[26] Jun M. Microphysical modeling of ultrafine hydrocarbon-containing aerosols in aircraft emissions. Doctorate thesis in aeronautics and astronautics. Massachusetts Institute of Technology; 2011.

[27] Tobias HJ, Beving DE, Ziemann PJ, Sakurai H, Zuk M, McMurry PH, et al. Chemical analysis of diesel engine nanoparticles using a nano-DMA/thermal desorption particle beam mass spectrometer. Environ Sci Techno 2001;35:2233-43.

[28] Spicer CW, Holdren MW, Cowen KA, Joseph DW, Satola J, Goodwin B, et al. Rapid measurement of emissions from military aircraft turbine engines by downstream extractive sampling of aircraft on the ground: results for C-130 and F-15 aircraft. Atmos Environ 2009;43:2612-22.

[29] Slemr F, Giehl H, Habram M, Slemr J, Schlager H, Schulte P, et al. J Geophys Res 2001;106:7485-94.

[30] Anderson BE, Chen G, Blake DR. Hydrocarbon emissions from a modern commercial airliner. Atmos Environ 2006;40:3601-12.

[31] Herndon SC, Jayne JT, Lobo P, Onasch TB, Fleming G, Hagen DE, et al. Commercial aircraft engine emissions characterization of in-use aircraft at Hartsfield-Jackson Atlanta International Airport. Environ Sci Technol 2008;42:1877-83.

[32] Yelvington PE, Herndon SC, Wormhoudt JC, Jayne JT, Miake-Lye RC, Berk Knighton W, et al. Chemical speciation of hydrocarbon emissions from a commercial aircraft engine. J Propuls Power 2007;23:912-8.

[33] Knighton WB, Herndon SC, Wood EC, Timko MT, Miake-Lye RC. VOC emissions from jet aircraft engines burning alternative fuels, a summary of the alternate aviation fuel experiment (AAFEX). NASA; 2011.

[34] Knighton WB, Herndon SC, Miake-Lye RC. Aircraft engine speciated organic gases: speciation of unburned organic gases in aircraft exhaust. EPA; 2009.

[35] Brock JR, Bird RB. Surface tension and the principle of corresponding states. AIChE J 1955;1:174-7.

[36] Sastri SRS, Rao KK. A simple method to predict surface tension of organic liquids. Chem Eng J Biochem Eng J 1995;59:181-6.

[37] Poling BE, Prausnitz JM, O'Connell J. The properties of gases and liquids. 5th revised ed. McGraw-Hill Professional; 2000.
[38] Clegg SL, Seinfeld JH. Thermodynamic models of aqueous solutions containing inorganic electrolytes and dicarboxylic acids at $298.15 \mathrm{~K} .1$. The acids as nondissociating components. J Phys Chem A 2006;110:5692-717.

[39] Gierens K. On the transition between heterogeneous and homogeneous freezing. Atmos Chem Phys 2003;3:437-46.

[40] Kärcher B, Yu F. Role of aircraft soot emissions in contrail formation. Geophys Res Lett 2009;36:5.

[41] Curtius J, Arnold F, Schulte P. Sulfuric acid measurements in the exhaust plume of a jet aircraft in flight: implications for the sulfuric acid formation efficiency. Geophys Res Lett 2002;29:4.

[42] Katragkou E, Wilhelm S, Arnold F, Wilson C. First gaseous sulfur (VI) measurements in the simulated internal flow of an aircraft gas turbine engine during project PartEmis. Geophys Res Lett 2004;31:L02117.

[43] Schumann U, Arnold F, Busen R, Curtius J, Kärcher B, Kiendler A, et al. Influence of fuel sulfur on the composition of aircraft exhaust plumes: the experiments SULFUR 1-7. J Geophys Res 2002;107:2-27.

[44] Yu F, Turco RP. The role of ions in the formation and evolution of particles in aircraft plumes. Geophys Res Lett 1997;24:1927-30.

[45] Sorokin A, Vancassel X, Mirabel P. Emission of ions and charged soot particles by aircraft engines. Atmos Chem Phys 2003;3:325-34.

[46] Andronache C, Chameides WL. Interactions between sulfur and soot emissions from aircraft and their role in contrail formation. 1. Nucleation. J Geophys Res $1997 ; 102: 21443-51$

[47] Kärcher B. On the potential importance of sulfur-induced activation of soot particles in nascent jet aircraft exhaust plumes. Atmos Res 1998;46:293-305.

[48] Petzold A, Gysel M, Vancassel X, Hitzenberger R, Puxbaum H, Vrochticky S, et al. On the effects of organic matter and sulphur-containing compounds on the CCN activation of combustion particles. Atmos Chem Phys 2005;5:3187-203.

[49] Wong H-W, Yelvington PE, Timko MT, Onasch TB, Miake-Lye RC, Zhang J, et al. Microphysical modeling of ground-level aircraft-emitted aerosol formation: roles of sulfur-containing species. J Propuls Power 2008;24:590-602.

[50] Wong H-W, Miake-Lye RC. Parametric studies of contrail ice particle formation in jet regime using microphysical parcel modeling. Atmos Chem Phys 2010;10:3261-72.

[51] Henning S, Ziese M, Kiselev A, Saathoff H, Möhler O, Mentel TF, et al. Hygroscopic growth and droplet activation of soot particles: uncoated, succinic or sulfuric acid coated. Atmos Chem Phys 2012;12:4525-37.

[52] Hong G, Feng Q, Yang P, Kattawar GW, Minnis P, Hu YX. Optical properties of ice particles in young contrails. J Quant Spectrosc Radiat Transf 2008;109:2635-47.

[53] Zhang R, Khalizov AF, Pagels J, Zhang D, Xue H, McMurry PH. Variability in morphology, hygroscopicity, and optical properties of soot aerosols during atmospheric processing. Proc Natl Acad Sci 2008;105:10291-6.

[54] Schröder F, Kärcher B, Duroure C, Ström J, Petzold A, Gayet JF, et al. On the transition of contrails into cirrus clouds. J Atmos Sci 2000;57:464-80.

[55] Deshler T, Hervig ME, Hofmann DJ, Rosen JM, Liley JB. Thirty years of in situ stratospheric aerosol size distribution measurements from Laramie, Wyoming $\left(41^{\circ} \mathrm{N}\right)$, using balloon-borne instruments. J Geophys Res 2003;108:13.

[56] Kärcher B, Möhler O, DeMott PJ, Pechtl S, Yu F. Insights into the role of soot aerosols in cirrus cloud formation. Atmos Chem Phys 2007;7:4203-27.

[57] Corporan E, Dewitt MJ, Belovich V, Pawlik R, Lynch AC, Gord JR, et al. Emissions characteristics of a turbine engine and research combustor burning a FischerTropsch jet fuel. Energy Fuels 2007;21:2615-26.

[58] Hileman JI, Wong HM, Ortiz D, Brown N, Maurice L, Rumizen M. The feasibility and potential environmental benefits of alternative fuels for commercial aviation. Proc 26th Int Congr Aeronaut Sci 2008.

[59] Spicer CW, Holdren MW, Riggin RM, Lyon TF. Chemical composition and photochemical reactivity of exhaust from aircraft turbine engines. Ann Geophys 1994;12:944-55. 